\title{
Diversity of patterns and processes in rivers of eastern Andalusia
}

\author{
J. Jesús Casas ${ }^{1}$, Mark O. Gessner ${ }^{2}$, Peter H. Langton ${ }^{3}$, Demetrio Calle ${ }^{4}$, Enrique Descals ${ }^{5}$ \\ y María J. Salinas ${ }^{1}$
}

${ }^{1}$ Departamento de Biología Vegetal y Ecología, Universidad de Almería, 04120-Almería.

${ }^{2}$ Department of Aquatic Ecology, Swiss Federal Institute of Aquatic Science and Technology (Eawag), and Institute of Integrative Biology (IBZ), ETH Zurich, Suiza

${ }^{3}$ Cambridge University Museum, Cambridge, Reino Unido

${ }^{4}$ Instituto de Enseñanza Media "Los Manantiales", Torremolinos, Málaga.

${ }^{5}$ Instituto Mediterráneo de Estudios Avanzados (IMEDEA), CSIC/UIB, Palma, Mallorca

Corresponding autor: J. J. Casas (jjcasas@ual.es)

\begin{abstract}
We document the outstanding diversity of fluvial ecosystems in eastern Andalusia, mostly attributable to the high environmental heterogeneity of the region. The area's altitudinal and climatic gradients are among the most pronounced in the Iberian Peninsula, and together with a concomitant high variability in geological characteristics and human impacts, result in a noticeable heterogeneity of the rivers' thermal regime, discharge regime and chemical properties. Fluvial communities respond to this spatial heterogeneity with marked qualitative and quantitative changes among rivers and along the upstream-downstream continuum, generally exhibiting a great decrease in taxonomic and functional diversity as human impacts increase towards the lower reaches. Discharge fluctuations add heterogeneity on the temporal scale and are an additional essential determinant of biological diversity. Climatic, geological and hydrological characteristics profoundly affect the structure of the riparian vegetation, which in turn strongly conditions the community structure of benthic macroinvertebrates and organic matter turnover in fluvial ecosystems.
\end{abstract}

Key words: rivers, eastern Andalusia, environmental gradients, human impacts, macroinvertebrates, chironomids, riparian vegetation, leaf litter decomposition, aquatic hyphomycetes.

\section{RESUMEN}

Se ilustra la notable diversidad de ecosistemas fluviales de Andalucía Oriental, atribuible a la gran heterogeneidad ambiental de esta región. Gradientes altitudinales y climáticos de los más pronunciados de la península Ibérica, concomitantes con una gran variedad de condiciones litológicas y de impactos humanos, acentúan en esta región la heterogeneidad térmica, de caudal y calidad quimica de los rios. Las comunidades fluviales responden a esta heterogeneidad espacial con profundos cambios cualitativos y cuantitativos, y generalmente con una disminución de la diversidad taxonómica y funcional en respuesta al incremento de impactos humanos hacia los tramos bajos de los rios. Las fluctuaciones de caudal suman heterogeneidad en la dimensión tiempo, y constituyen un determinante esencial de los patrones de diversidad biológica. La estructura de la vegetación de ribera responde con grandes cambios a las condiciones climáticas, litológicas e hidrológicas, y ésta a su vez condiciona sustancialmente el marco trófico del ecosistema fluvial.

Palabras clave: ríos, Andalucía oriental, gradientes ambientales, impactos humanos, macroinvertebrados, quironómidos, vegetación de ribera, descomposición de hojarasca, hifomicetos acuáticos.

\section{INTRODUCTION}

Margalef $(1960,1983)$ highlighted as an essential characteristic of fluvial ecosystems their large interfaces with the surrounding landscape. This means that the climatic, geomorphic and biological setting of river basins strongly condition the structural and functional traits of river communi- ties (Hynes, 1970; Allan, 1995). This idea was behind Gasith \& Resh's (1999) proposal of a functional convergence of rivers under Mediterranean climate. The most general characteristic of the Mediterranean climate is the strong seasonality of precipitation, which tends to be concentrated in a few events mostly occurring during winter, and with high variability between 
years. According to Gasith \& Resh (loc. cit.), this pattern determines an annual sequence of predictable flood events (autumn-winter), during which the fluvial ecosystem is under abiotic control, followed by periods of stable flow (spring-summer) during which biotic control dominates.

Although broadly speaking the above-mentioned convergence may occur, these authors and others (e.g. Blondel \& Aronson, 1999) also recognise the great climatic diversity of the Mediterranean basin, together with the considerable heterogeneity of geomorphic features and human uses of rivers and surrounding land, which make generalisations difficult. For instance, both the highest and lowest precipitation in Europe occur in the Mediterranean basin, namely in the coast of Montenegro (4640 mm) and Almería (150-200 mm) (Grove \& Rackham, 2001). At almost any spatial scale of observation the Mediterranean basin appears as a remarkably diverse mosaic, due to the extraordinary heterogeneity of topography, climate, geology and past and present human actions on the landscape (Monserrat, 1998; Blondel \& Aronson, 1999).

The present review aims to document, from a regional perspective, the diversity of ecological patterns and processes in rivers of eastern Andalusia, one of the most mountainous European regions. The area includes the Sierra Nevada, the southernmost high mountain range on the continent, which strongly influences the surrounding areas. We also aim to document the consequences of human impacts on these rivers. The results summarised here come from studies we have carried out in this region over the last two decades.

\section{ENVIRONMENTAL CHARACTERISTICS}

\section{Physical, geological and climatic heterogeneity}

Eastern Andalusia includes a wide range of geological and climatic conditions. The Betic mountain ranges occupy most of the area, shaping an extraordinarily uneven relief. The mountain massif of the Sierra Nevada stands out with several peaks above $3000 \mathrm{~m}$ a.s.1., but several other sierras also reach altitudes above $2000 \mathrm{~m}$ a.s.1. (e.g.
Cazorla, Mágina, Tejeda, Filabres-Baza, Gador). The geology of the sierras is diverse, including Palaeozoic metamorphic rocks, particularly in the upper layers of the Sierra Nevada and FilabresBaza, and mostly calcareous rocks, marble and vast dolomitic outcrops extending mainly into the mid to low altitudes of most sierras. A peculiar trait of the Betic mountain ranges is the high abundance of calcareous sierras with a varied karstic relief, also including a gypsum karst (Durán \& López, 1999). This geologic diversity adds physical heterogeneity to the river courses of the area. Fluviokarstic canyons, for example, are a frequent landscape feature, particularly in the foothills of the sierras. Lowlands made up of continental, and frequently marine, sediments deposited during the Neogene period separated the sierras. These lowlands often comprise terrain composed of marl rich in sulphate and chloride.

The greatly compartmentalized relief of the Betic ranges favours high spatial heterogeneity in precipitation. Mean annual rainfall ranges from over $1000 \mathrm{~mm}$ at the heart of Sierra de Cazorla, or over $800 \mathrm{~mm}$ on the peaks of Sierra Nevada or Sierras de Tejeda-Almijara, to less than $200 \mathrm{~mm}$ in Cabo de Gata (Capel-Molina, 2000). Cyclonic events from the northwest or west are the most frequent, and provide most of the rainfall in the region, particularly on the western mountain slopes. On the eastern sides, especially of the Sierra Nevada owing to its high altitude, the descending cool and dry air tends to accentuate arid conditions (Föhn effect), e.g. in the subdesert of Tabernas. Cyclonic events from the east are less frequent but bring a great proportion of the rainfall to the eastern part of the region, mainly during storms towards the end of summer and autumn (Castillo-Requena, 1981).

\section{Heterogeneity of discharge regimes: natural and human constraints}

The annual hydrograph of rivers in eastern Andalusia generally fits to the Mediterranean pluvial subtropical type, which is characterised by very low flow in summer and peak discharge during winter (Fig. 1a). This regime is distinctly modified (i.e. peaking slightly during summer) 


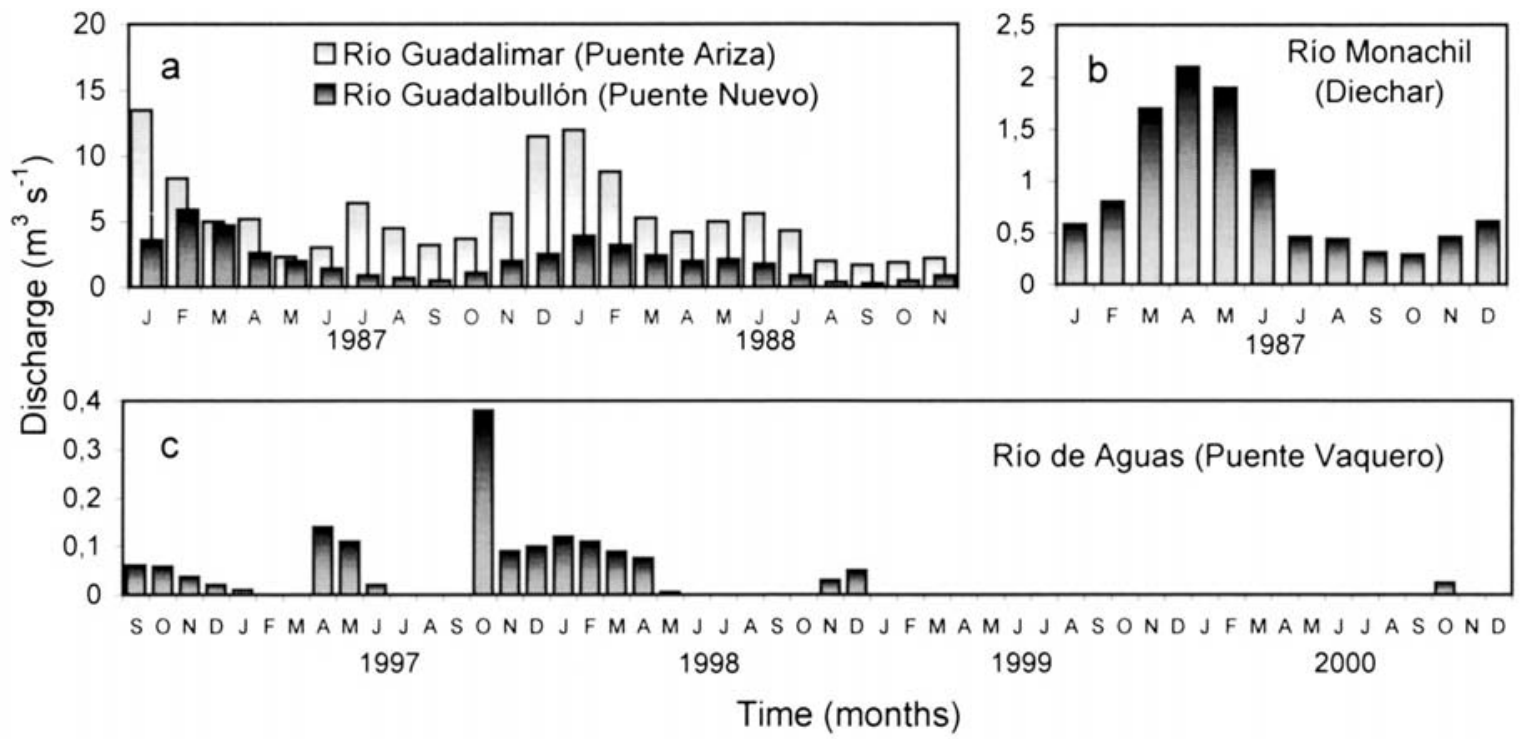

Figure 1. Discharge regimes in several Betic rivers: a) upper Río Guadalquivir; b) Río Monachil in the Sierra Nevada; c) Río de Aguas in eastern Almería. Regímenes de caudal registrados en distintas cuencas béticas: a) Alto Guadalquivir; b) Río Monachil en Sierra Nevada; c) Río de Aguas en el levante almeriense.

by reservoir regulation, particularly in the upper Río Guadalquivir, and mainly for agricultural purposes (Fig. 1a) (Calle et al., 1990). The abundance of groundwater sources up-welling from large karstic aquifers is noteworthy. It tends to confer rather constant discharge to rivers during summer. In fact, most permanent reaches in rivers from the most arid zone of the region (Almería) are fed by these karstic sources. The annual hydrograph of the rivers from the Sierra Nevada merit special attention in that it exhibits a pronounced snowmelt influence peaking between March and May (Fig. 1b) (Casas, 1990). The scarcity of rainfall and extreme concentration in a few events, together with the high permeability of the calcareous and/or evaporitic bedrocks, are responsible for the high percentage of temporary water courses in the fluvial networks. This ten-

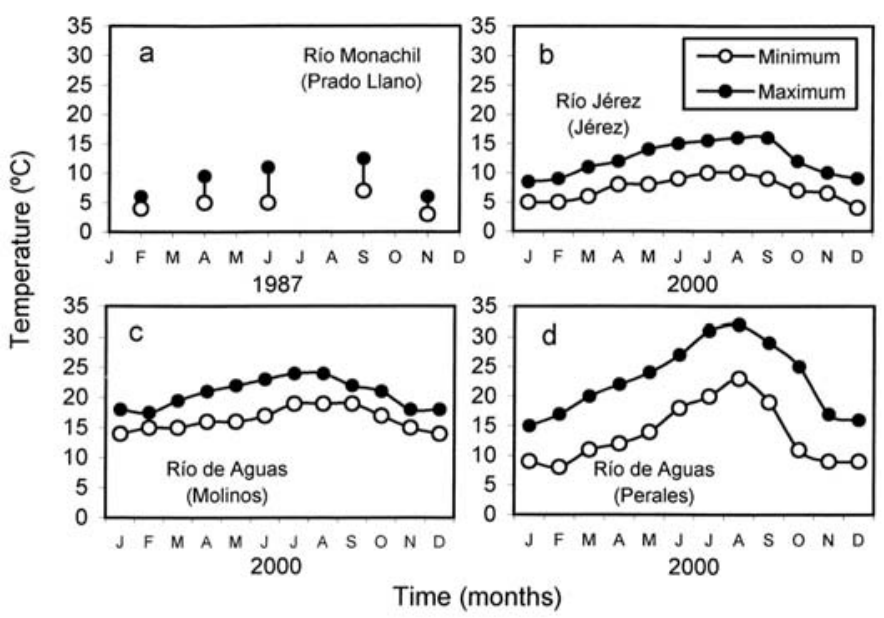

Figure 2. Thermal regimes in several streams located in the Sierra Nevada (Río Monachil at $2100 \mathrm{~m}$ a.s.1. and Río Jérez at $1280 \mathrm{~m}$ a.s.1.) and eastern Almería (Río de Aguas at Molinos, $265 \mathrm{~m}$ a.s.1., and Perales, $220 \mathrm{~m}$ a.s.1.). Río Monachil: maximum and minimum daily temperatures on 5 different dates in the year. Other streams: maximum and minimum monthly temperatures. Régimen térmico en varios ríos de cabecera de Sierra Nevada (Río Monachil y Río Jérez) y del litoral semiárido almeriense (Río de Aguas). Río Monachil: temperatura máxima-mínima diárias de 5 dias. Restantes ríos: temperaturas máximas-mínimas mensuales. 

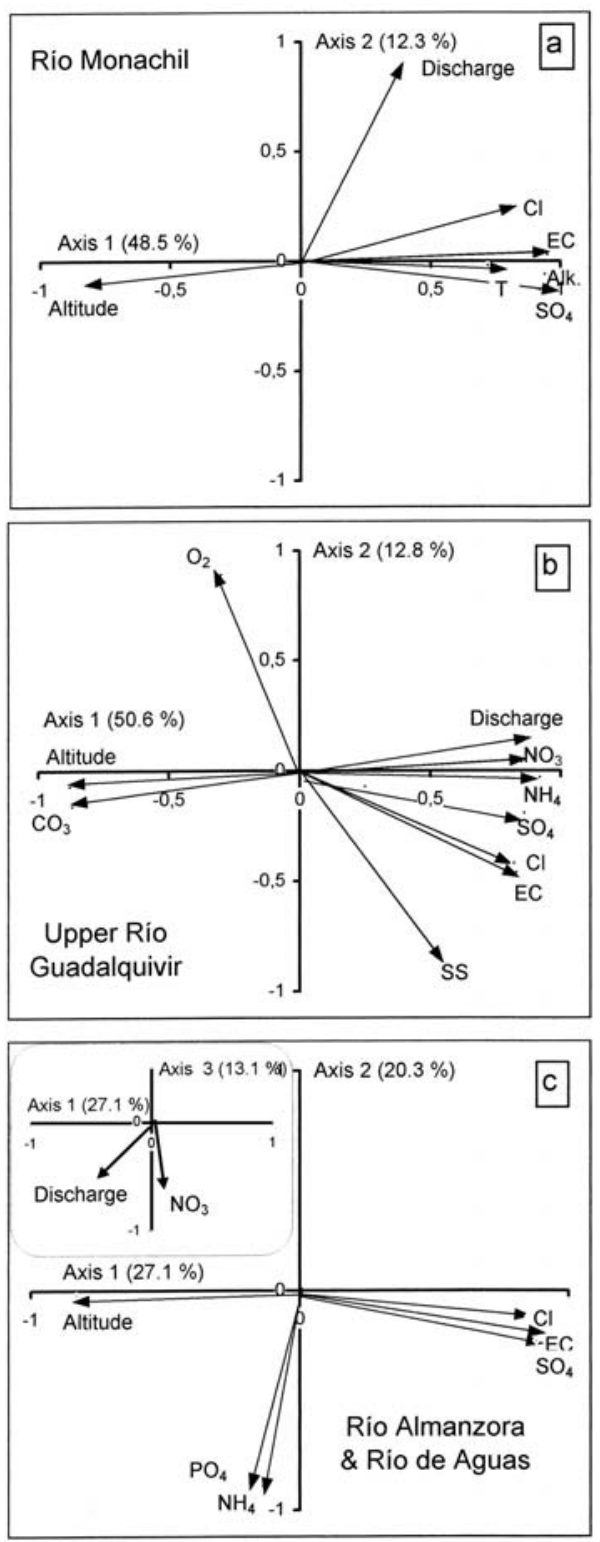

Figure 3. Results of principal component analyses (PCA) of physico-chemical characteristics of three river ecosystems: a) Río Monachil from the Sierra Nevada (Casas, 1996), b) the upper Río Guadalquivir (Calle et al., 1990), and c) Ríos Almanzora and Aguas in eastern Almería (Vivas et al., 2001). The percentage of variance explained by the PCA axes is indicated in parentheses. A third axis is presented for the rivers in eastern Almería. Resultados del análisis de componentes principales (ACP) para las características fisicas y químicas de las aguas de tres ecosistemas fluviales: a) Río Monachil en Sierra Nevada (Casas, 1996), b) Alto Guadalquivir (Calle et al., 1990), y c) cuencas de los ríos Almanzora y Aguas en el levante almeriense (Vivas et al., 2001). El porcentaje de varianza explicada por cada eje se indica entre paréntesis. Para los ríos almerienses se indican también los resultados del tercer eje extraido por el ACP. dency is most noticeable in the semiarid east of the region and in most lowland reaches, where water abstraction for agriculture and human settlements dries up many river courses (Fig. 1c).

\section{Physico-chemical variability of water quality: the influence of altitudinal gradients and geological and human factors}

The thermal regime of rivers is considered a primer determinant of diversity patterns of aquatic communities along altitudinal-longitudinal gradients (Ward \& Stanford, 1982; Jacobsen et al., 1997). The pronounced altitudinal gradient of the Betic ranges in such a southern region results in marked differences in temperature both between and within river basins (Fig. 2). Streams above tree line in the Sierra Nevada exhibit the lowest temperatures, with minimum values around $2{ }^{\circ} \mathrm{C}$ and summer maxima below $13{ }^{\circ} \mathrm{C}$ (Fig. 2a) (Casas, 1990), not much unlike other alpine streams (Milner et al., 2002). The middle and foothill reaches of the rivers often have closed canopies and higher discharge. Minimum temperatures do not usually fall below $5{ }^{\circ} \mathrm{C}$ in these reaches, and maximum values rarely surpass $20^{\circ} \mathrm{C}$ (Fig. 2b). In contrast, summer temperatures in reaches flowing in the lowlands often greatly surpass $20{ }^{\circ} \mathrm{C}$, particularly in the semiarid eastern area. The Río de Aguas, which originates at $260 \mathrm{~m}$ a.s.1. and less than $15 \mathrm{~km}$ from the Mediterranean coast, illustrates the strong influence of karstic springs, riparian vegetation and discharge on the thermal regime of Mediterranean rivers: Seasonal temperature fluctuations are minor at Molinos, less than $1 \mathrm{~km}$ from the source, where ground water is upwelling from the gypsum karst of Sorbas and the cover by riparian tress and reeds is about $80 \%$ (Fig. 2c). The site at Perales, in contrast, has sparse riparian vegetation and is impacted by water abstraction for irrigation; it is located only $2 \mathrm{~km}$ further downstream but shows strong annual thermal fluctuations (Fig. 2d).

The impact of reservoir regulation often produces a net attenuating effect on temperature amplitudes. For instance, the upper Río Guadalquivir at Charco del Aceite, $6 \mathrm{~km}$ downstream from the Tranco reservoir, exhibits relatively narrow diel 

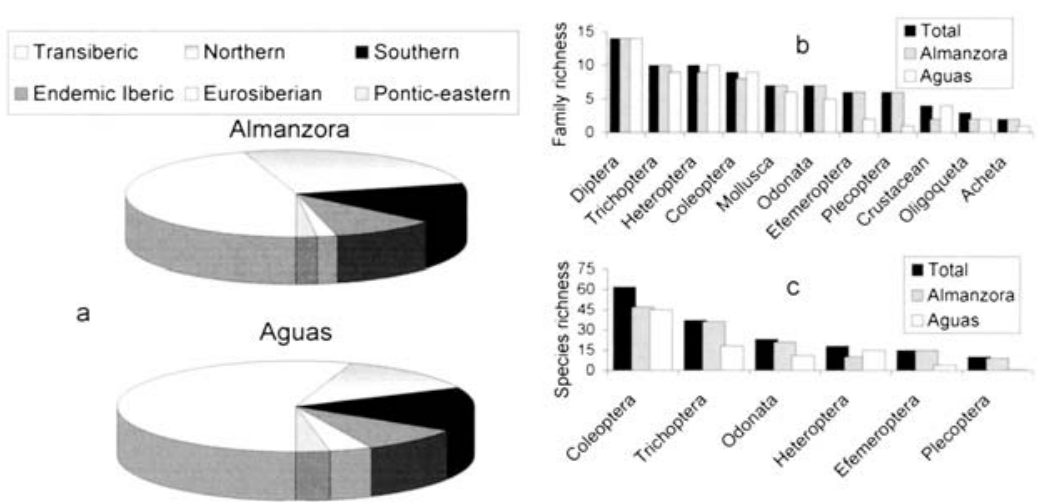

Figure 4. a) Percentages of species of the major taxonomic groups of macroinvertebrates present (except Diptera) with different biogeographical distribution: Transiberic species (present in Europe, the Iberian Peninsula and North Africa); northern species (transiberic species absent from North Africa); southern species (transiberic species absent beyond the Pyrenees). b) Family richness and c) species richness of the main taxonomic groups of macroinvertebrates combined for the two river basins studied (total) and for each basin separately. a) Porcentajes de especies (excepto dipteros) según su distribución biogeográfica: Transibéricos, presentes en Europa, Peninsula Ibérica y Norte de África; Norteños, transibéricos que no alcanzan el Norte de África; Sureños, transibéricos que no traspasan los Pirineos. b) Riqueza de familias, y c) riqueza de especies, de los principales grupos taxonómicos en las dos cuencas almerienses estudiadas (total) y en cada una por separado.

thermal oscillations and less extreme minima $\left(10-11,13-14,17-21\right.$ and $18-21^{\circ} \mathrm{C}$, respectively, in December, March, June and August) compared to the Santo Tome site, located $45 \mathrm{~km}$ downstream from the same reservoir (10-15, 9-21 and $7-12^{\circ} \mathrm{C}$, respectively, in January, April and November) (Calle et al., 1990).

On the river basin scale, the increase in ionic content from the headwaters to the lowland reaches is the most evident pattern of spatial variation in the rivers of eastern Andalusia (Fig. 3), as is commonly found in rivers worldwide (Margalef, 1983; Allan, 1995). This pattern may mainly be attributable to a marked altitudinal transition of geological formations: e.g. from siliceous to calcareous rocks in the Sierra Nevada (Río Monachil, with electrical conductivity ranging from 33-358 $\mu \mathrm{S} \mathrm{cm}^{-1}$ ) (Casas, 1996); from calcareous to marl rocks in the upper Río Guadalquivir (conductivity ranging from $376-2960 \mu \mathrm{S} \mathrm{cm}^{-1}$ ) (Calle et al., 1990); or from siliceous to evaporitic rocks in the Río Almanzora (conductivity ranging from $150-8000 \mu \mathrm{S} \mathrm{cm}^{-1}$ ) (Vivas et al., 2001) (Fig. 3). Evaporation may also be important. In the intermittent Río de Aguas, for example, several permanent pools remaining during summer reach conductivity values of over $11 \mathrm{mS} \mathrm{cm}^{-1}$.

In the western catchments, such as in the upper Rio Guadalquivir (Fig. 3b), the longitudinal gra- dient is more strongly related to increasing nitrogen concentrations downstream than to ionic content of the river water in general. This is due to prominent diffuse and point-source contamination caused by intensive agricultural activities and abundant human settlements in the olive-growing areas of Jaén. In this river, discharge shows a net increase downstream despite important water abstractions, probably due to the high number of relatively large tributaries. In the olive countryside of Jaén, as in many lowland reaches of western Andalusia, pollution by suspended solids shows strong seasonality. During winter-spring, surface runoff transports clay to the river from the nearby olive orchards, and there are also frequent inputs of olive-mill waste (alpechín), which increase the concentration of suspended solids and oxygen demand (axis 2 in Fig. 3b). Another notable feature of this river, which is widespread also in other calcareous sierras, is the high carbonate concentration in the headwaters (Fig. 3b), which makes calcite precipitation a common event and may lead to important tuff formation (Calle et al., 1990; Casas et al., 1994; Casas \& Gessner, 1999).

In eastern basins (Almería) the fluvial continuum is normally fragmented as a result of the arid climate and impoundments built for agricultural irrigation. Lowland reaches only carry water after marked rainfall events or where 
springs generate isolated permanent or temporary pools. In these fluvial networks, wastewater pollution does not continuously increase downstream (axis 2 in Fig. 3c), but is rather limited to a few sites. This is probably because wastewaters that would normally be discharged into them are often diverted into the aquifer. Additionally, the human population density here is lower than in the western basins. In the eastern semiarid basins rainfall events are the main source of discharge variability, which is positively related to nitrate concentrations, probably due to inputs originating from agricultural soil lixiviation (axis 3 in Fig. 3c) (Vivas et al., 2001).

\section{MACROINVERTEBRATE DIVERSITY PATTERNS: NATURAL AND HUMAN CONSTRAINTS}

The Mediterranean basin, particularly the Betic region, is a biodiversity hot spot on the global scale (Médail \& Quézel, 1999; Myers et al., 2000). The extraordinary species richness of the area may be attributable to its present environmental heterogeneity, its special geographical location, and the diverse climatic and geological changes in the past, which have led many taxa from different biogeographical origins to colonise, find refuges and/or radiate (Blondel \& Aronson, 1999). Two fluvial basins in Almería illustrate the variety of biogeographical origins and distributions of macroinvertebrate taxa (Fig. 4a) (Vivas et al., 2002; Vivas, 2003). In both river systems, the dominant taxa have a transiberic distribution (Central Europe-North Africa), but taxa endemic to the Iberian Peninsula were also relatively abundant $(10 \%)$. The main difference between basins, Almanzora vs. Aguas, lies in the high percentage of taxa with a northern distribution (i.e. taxa absent in North Africa). These taxa are present in mountain sites of the Río Almanzora basin, but are absent in the lowland basin of the Río de Aguas. Plecoptera, Ephemeroptera, Trichoptera, Odonata and Coleoptera species, which during their larval stages or, in the case of Coleoptera, during their entire life cycle require cool water and moderate hardwater condi- tions which characterise the mountain headwaters of the Río Almanzora (Fig. 4 b and c). In the Río de Aguas, on the other hand, the relatively high temperature and ionic content, plus the abundance of pools with aquatic vegetation, provide favourable habitats for Heteroptera and Crustacean.

On the basin scale of the rivers Almanzora and Aguas, macroinvertebrate communities are primarily structured by the longitudinal increases in salinity and temperature towards the lower reaches (Vivas, 2003) (Table 1), similar to the trend observed in 12 basins studied across the Spanish Mediterranean region (Vivas et al., 2002). Furthermore, in the semiarid basins this longitudinal gradient was also negatively correlated with discharge and riparian cover by deciduous woody vegetation, which greatly diminishes towards the lower reaches. Although the overall taxonomic richness of benthic macroinvertebrates is not significantly correlated with these longitudinal changes in environmental conditions, the rich-

Table 1. Spearman correlations of environmental variables and taxonomic richness, with Axes 1 and 2 determined by a canonical correspondence analysis of the environmental variables-macroinvertebrate taxa matrix. Level of significance, $* \mathrm{p}<0.05$. Correlaciones de Spearman de variables ambientales y riqueza taxonómica en lo ejes 1 y 2 extraídos por un análisis canónico de correspondencias ambiente-taxones de macroinvertebrados. Nivel de significación, $* p<0,05$.

CCA Axis 1 CCA Axis 2

\begin{tabular}{lrrr} 
Environmental variables & & & \\
Electrical conductivity & $0.85 *$ & -0.10 \\
Temperature & $0.46 *$ & -0.10 \\
Discharge & $-0.44 *$ & -0.61 & $*$ \\
Hydroperiod span & -0.20 & $-0.75 *$ \\
Index of physical impacts & 0.14 & $0.83 *$ \\
Deciduous vegetation cover & $0.80 *$ & -0.02 \\
Emergent macrophytes cover & $0.49 *$ & $-0.64 *$ \\
\hline Taxa richness & & & \\
Total richness & & & \\
Ephemeroptera & 0.01 & $-0.79 *$ \\
Plecoptera & $-0.40 *$ & $-0.65 *$ \\
Trichoptera & $-0.61 *$ & $-0.31 *$ \\
Odonata & $-0.30 *$ & $-0.66 *$ \\
Coleoptera & $0.44 *$ & $-0.75 *$ \\
Heteroptera & $0.30 *$ & $-0.59 *$ \\
Diptera & $0.58 *$ & $-0.46 *$ \\
Mollusca & $0.36 *$ & $-0.39 *$ \\
Crustacean & $0.12 *$ & $-0.55 *$ \\
\hline
\end{tabular}


Table 2. Transformed values of basin $\gamma$-richness (i.e. $\gamma$-richness / ln number of samples), with untransformed values shown in parentheses; average local $\alpha$-richness; and average basin $\beta$-richness calculated as the percentage dissimilarity between pairs of sites (Sørensen index). The altitudinal range and the proportion of temporary study sites are also shown. Betic basins are shaded. Data extracted form GUADALMED-1 database (modified from Vivas, 2003). Riqueza de cuenca, valor transformado ( $\gamma$-riqueza / In $n^{o}$ de muestras), y valor absoluto entre parentesis. $\alpha$-Riqueza media por localidad y $\beta$-riqueza media de la cuenca, calculado como el porcentaje de disimilitud entre pares de localidades (indice de Sorensen). Se muestra el intervalo altitudinal y el porcentaje de localidades temporales estudiadas. Las cuencas béticas se han sombreado. Datos tomados de la base de datos GUADALMED-1 (modificado de Vivas, 2003).

\begin{tabular}{lcccrr}
\hline Fluvial basin & $\boldsymbol{\gamma}$-Richness & $\boldsymbol{\alpha}$-Richness & $\boldsymbol{\beta}$-Richness & Altitudinal range (m) & \% Temporality \\
\hline Adra & $23(85)$ & 45 & 0.43 & 2060 & 0 \\
Segura & $22(102)$ & 46 & 0.34 & 1413 & 22 \\
Llobregat & $20(94)$ & 40 & 0.34 & 1200 & 7 \\
Besos & $20(93)$ & 37 & 0.36 & 1505 & 40 \\
Jucar & $20(84)$ & 31 & 0.35 & 1520 & 0 \\
Turia & $20(77)$ & 27 & 0.33 & 1500 & 21 \\
Mijares & $20(71)$ & 30 & 0.39 & 1270 & 45 \\
Soller & $18(51)$ & 24 & 0.40 & 270 & 100 \\
Almanzora & $17(74)$ & 28 & 0.38 & 325 & 73 \\
Aguas & $17(64)$ & 34 & 0.39 & 2980 & 90 \\
Pollença & $17(60)$ & 30 & 0.41 & 0.36 & 19 \\
Guadalfeo & $16(76)$ & 41 & & \\
\hline
\end{tabular}

ness of particular groups changes markedly, with Ephemeroptera, Plecoptera and Trichoptera being gradually replaced by species from other groups towards downstream sites characterised by high summer temperatures and salinity (Table 1). A second environmental gradient is positively related to the shortening of the hydroperiod and extent of anthropogenic impact on channel morphology, which both have negative effects on total macroinverterate richness and on richness within specific taxonomic groups (Table 1). Temporary reaches with short hydroperiods and close to human settlements are frequently used by farming vehicles. The resulting high frequency and magnitude of impacts on river channels reduces physical heterogeneity of aquatic habitats and impairs water quality.

A comparative analysis of macroinvertebrate family studied among 12 Mediterranean basins revealed an unusually large heterogeneity of diversity patterns in the Betic basins. This result may be mainly due to the wide range of altitudes and temporality of the studied aquatic habitats (Table 2) (Vivas, 2003). Accordingly, $\gamma$-richness of macroinvertebrates at the basin scale showed a significant positive correlation with altitudinal range and a significant negative correlation with the percentage of temporary aquatic sites $\left(r_{s}=0.72\right.$ and $r_{s}=-0.78$, respectively, $\left.p<0.05\right)$, whereas it was not significantly correlated with basin surface area as would be expected from the general species-area relationship. The permanence of fluvial habitats appears to affect local $\alpha$-richness positively, as suggested by higher than average $\alpha$-richness in the Río Guadalfeo and Río Adra in the Sierra Nevada, where all sites studied were permanent. Moreover, the great altitudinal gradient in these basins appears to favour a relatively high $\beta$-richness. It is well known that the wider the altitudinal range in a basin, the greater the habitat heterogeneity, with corresponding positive effects on taxa richness on this scale (Giller \& Malmqvist, 1998; Jacobsen, 2004). On the other hand, basins with a high percentage of temporary sites generally exhibited relatively low values of local $\alpha$-richness, although this effect may be somewhat offset by high basin $\beta$-richness (e.g. Almanzora and Aguas) (Table 2). The intermittent discharge regime of Mediterranean rivers, whether due to natural or human causes or both, induces fragmentation of the fluvial continuum, which in turn reduces longitudinal connectivity (e.g. Gasith \& Resh, 1999; Boulton, 2003; Lake, 2003). This process tends to diversify fluvial habitats among reaches that are hydrologically isolated, possibly by favouring a stronger influence of 

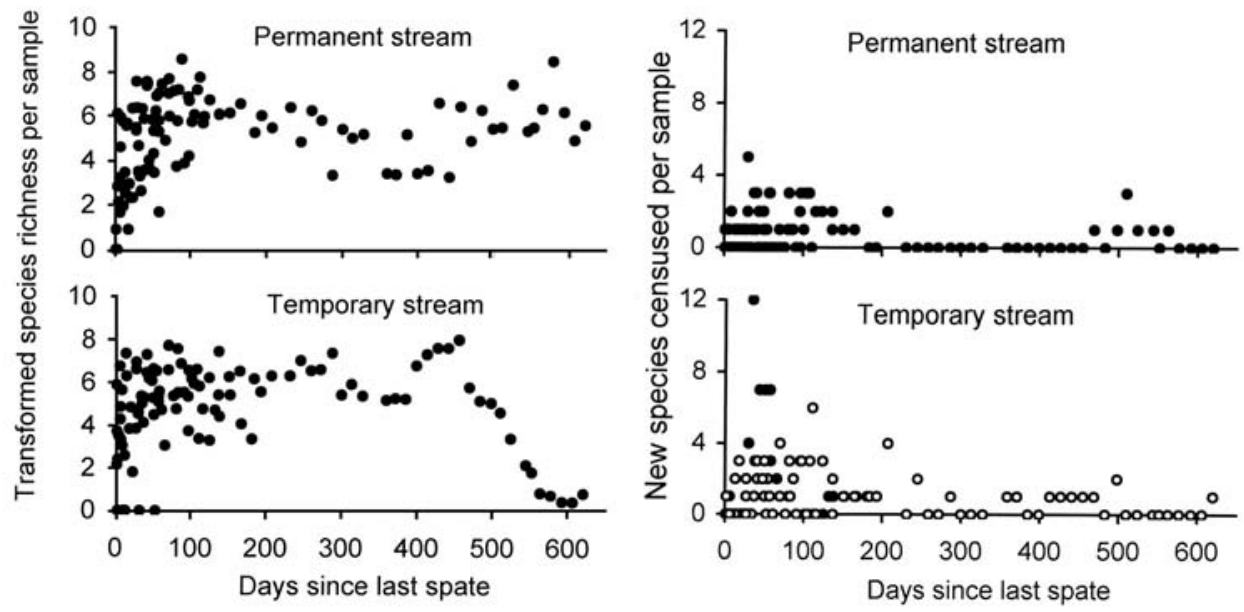

Figure 5. Dynamics of chironomid species from March 1996 to March 2000 (fortnightly sampling intervals) in two mountain streams of the Sierra de Albuñuelas (southern Granada) as a function of time elapsed since the last spate. Species number per sample was transformed according to the richness index proposed by Margalef (1982). The plot of the upper right panel takes into account the species list of the previous period of stable flow during the long-lasting drought from 1991-1995. For the temporary stream the first study year (1996, closed circles) was distinct from later years (1997-2000, open circles). Dinámica de las especies de quironómidos durante el periodo marzo-1996 a marzo-2000 (muestreos quincenales) en dos arroyos de cabecera de la Sierra de Albuñuelas (sur de Granada) en función del tiempo transcurrido desde la última avenida. El número de especies por muestra fue transformado según el índice de riqueza de Margalef (1982). En el gráfico de nuevas especies colectadas, para el río permanente se ha tenido en cuenta la lista de especies del periodo previo con caudal estable durante la prolongada sequía (1991-1995); para el río temporal se ha diferenciado el primer año de estudio (1996, circulos cerrados) de los posteriores (1997-2000, circulos abiertos).

local factors as opposed to upstream basin factors, and also by suppressing downstream drift.

\section{Chironomid species richness and indicator value}

Diptera, particularly Chironomidae, are an ubiquitous, species rich and the often most abundant group of macroinvertebrates in fluvial ecosystems. However, this group is rarely identified to species or genus level in ecological studies of fluvial benthos, due to the difficulty of identifying larvae. Chironomid pupal exuviae are easier to identify thanks to their more distinctive morphological features. Using this approach, the chironomid communities of rivers in the Sierra Nevada and the upper Río Guadalquivir in the Sierra de Cazorla were compared in order to determine the indicator value of this group at species level. The study revealed high species richness of chironomids in the two regions (total of 204 species) and the group's remarkable value for the biological classification of rivers (Calle $\&$ Casas, 2006). Two major groups of rivers were distinguished when using chironomid species as association criteria, clearly reflecting the two geographical locations. Obviously, there are pronounced enough differences between the rivers of both regions, including higher slopes and altitudes in the Sierra Nevada coupled with geological and hydrological differences, for the rivers to harbour distinctive chironomid communities. Interestingly, however, the sites studied on the Río Aguas-Blancas (Sierra Nevada) showed local characteristics close to those of rivers in the headwaters of the upper Río Guadalquivir (gentle slope, pluvial discharge regime and travertine precipitation), but faunistically were closer to the Sierra Nevada rivers. This suggests a preponderant role of regional rather than local factors determining chironomid species distribution. This pattern may well reflect a strong geographical "proximity effect", sensu Hawkins et al. (2000), on the source-sink dynamics of midge populations, coupled with considerable aerial colonising capacities of adults and the strong seasonal dynamics of fluvial ecosystems in eastern Andalusia. 
Temperature and especially the extent of water pollution were the primary determinants of chironomid community composition within both regions. Six chironomid species showed a significant indicator value for sites with impaired water quality (Chironomus riparius, Eukiefferiella claripennis, Paratrichocladius rufiventris, Rheocricotopus chalybeatus, Cricotopus bicinctus, and Tvetenia calvescens). The indicator values of these species cover a wide gradient of water quality impairment and occurrence of the species did not depend on the regional setting, whether in eastern Andalusia or elsewhere in European rivers, suggesting great potential for biomonitoring purposes (Calle \& Casas, 2006).

\section{Chironomid diversity and hydrological disturbance}

The highly irregular rainfall among years is characteristic of Mediterranean climate, determining extreme discharge fluctuations, which in turn are considered the key factor for fluvial ecosystem dynamics (e.g. Boulton et al., 1992; Sabater et al., 1992). The southern part of the Iberian Peninsula was affected by drought from 1992-95, ending with heavy rains in winter 1995-96. These events caused profound changes in the chironomid communities in two first-order Betic mountain streams, one permanent and the other temporary. From 1991-95 the permanent stream showed no peaks in discharge, which decreased progressively till December 1995, and the chironomid assemblage was dominated by species of the subfamily Tanytarsini. The temporary stream had no surface water flow during these four years. Heavy rains in winter 1995-96 ended the drought and caused extraordinary discharge peaks and transport of benthic materials in both the permanent and temporary stream. Once the river bed had become more stable the dominant species were those typically associated with torrential lowtemperature mountain streams, belonging to the genera Diamesa, Eukiefferiella and Orthocladius in both streams (Langton \& Casas, 1999).

In contrast to several other studies (e.g. Williams, 1996; Rüegg \& Robinson, 2004), which have found lower macroinvertebrate diversity in temporary aquatic habitats compared to perma- nent ones, the intermittent and permanent stream showed a similar overall chironomid species richness and mean richness per sample. This unexpected resemblance may have been due to the long period of surface water permanence in the temporary stream (1996-2000) following the drought in the first half of the 1990s. In addition, the temporary stream showed a greater temporal $\beta$-richness, a feature that could be attributable to higher temporal thermal variability and substrate heterogeneity compared to the permanent stream. The observed pattern of species richness variation as a function of time elapsed since the last spate is in general agreement with the patch dynamics concept in streams (Townsend, 1989). In both streams, spates favoured records of new species but hardly affected sample $\alpha$-richness (Fig. 5). On the other hand, prolonged periods without spates $(>1$ year) favoured records of new species in the permanent stream, but in the temporary stream this led to a disruption of flow an isolation of a few remaining pools which harboured an extremely impoverished chironomid assemblage (Fig. 5).

Apart from the similar overall chironomid $\gamma$-richness, the two examined streams also exhibited similar mean values of species rarity and notable species assemblage complementarity (20\%). These results corroborate other studies which have stressed the high conservation value of temporary aquatic habitats, so frequently neglected, and the need to include them in plans for nature conservation. Although headwater streams in the Mediterranean are typically much less impacted by human actions than lower river reaches, agricultural activity in the catchments of headwaters is increasing, promoted in part by EU subsidies. In eastern Andalusia, this is particularly true for the expansion of olive groves and almond orchards, which is likely to exacerbate impacts on temporary stream habitats and diversity of the associated aquatic fauna.

\section{RIPARIAN VEGETATION, RESOURCE USE AND THE FLUVIAL FOOD WEB}

Fluvial ecosystems are landscape elements characterised by intense interactions between the 


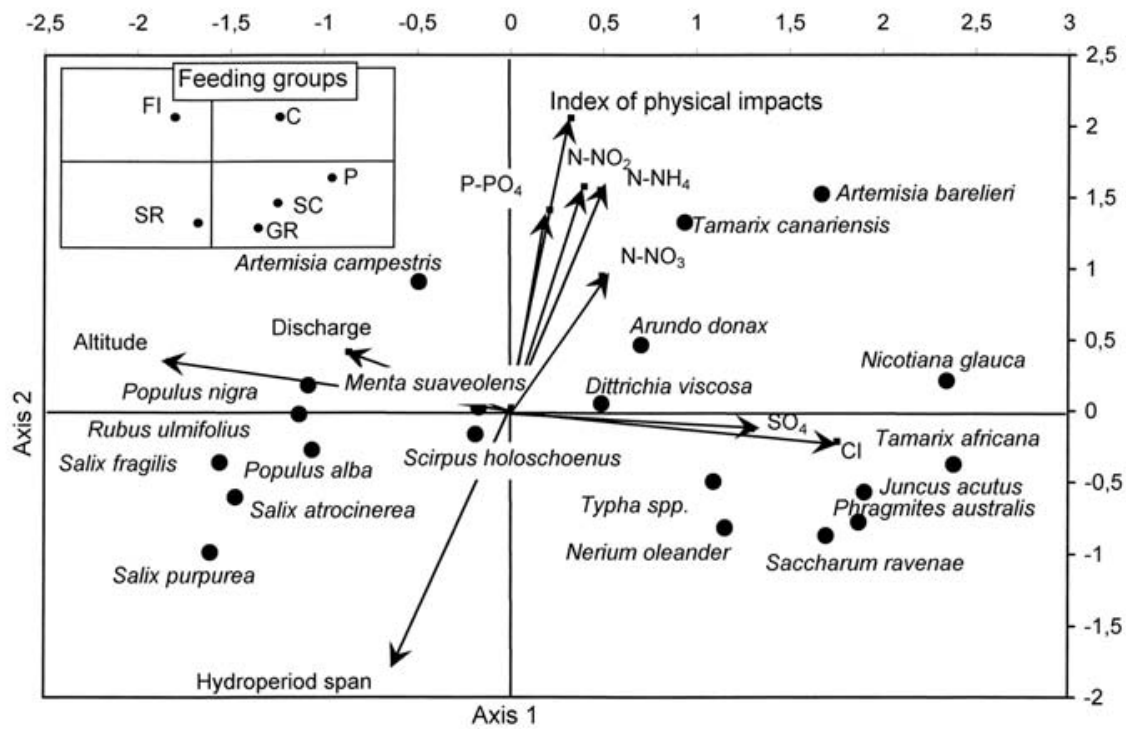

Figure 6. Results of a canonical correspondence analysis (CCA Axes 1 and 2) based on a biotic matrix of tree and shrub species (percentage cover data) and an abiotic matrix of fluvial environmental variables. Only the most abundant species and the environmental variables significantly correlated with the axes shown. The box in the top left-hand corner shows the ordination of macroinvertebrate functional feeding groups (relative abundance data) resulting from a CCA using the same environmental variables as the CCA for the vegetation: $\mathrm{FI}=$ Filterers, $\mathrm{C}=$ Collector-gatherers, $\mathrm{SR}=$ Shredders, $\mathrm{GR}=$ Grazers, $\mathrm{SC}=\mathrm{Scrapers}, \mathrm{P}=\mathrm{Predators}$. Resultados de un análisis canónico de correspondencias (ACC ejes 1 y 2) de las especies de árboles y arbustos (datos de cobertura) constreñidas por variables ambientales del río. Se indican las especies más abundantes y las variables ambientales (vectores) con correlación significativa con alguno de los ejes. Arriba a la izquierda se indica la ordenación de los grupos tróficos funcionales de macroinvertebrados (datos de abundancia relativa) resultante de un ACC utilizando las mismas variables ambientales: FI = filtradores, $C$ = colectores, $S R=$ fragmentadores, $G R=$ ramoneadores, $S C=$ raspadores, $P=$ depredadores.

river channel and riparian vegetation (Malanson, 1993). The climatic setting, hydrological dynamics and channel structure are of prime importance for riparian vegetation, which in turn determines essential traits of the fluvial benthic community (e.g. Gregory et al., 1991; Naiman et al., 2005). A study carried out in the rivers Almanzora and Aguas (Almería) illustrates how strong environmental gradients in these river basins affect the structure of riparian vegetation (M.J. Salinas \& J.J. Casas, unpublished data). As for macroinvertebrate communities (see above), the altitudinal-longitudinal gradients determine the major structural changes of vegetation: a decrease in richness and percentage cover of deciduous species downstream and an increase in emergent macrophytes, phreatophytes and halophytes or halotolerant species. These changes appear to be related to the hydrological decay of rivers and a concomitant increase in salinity towards the lowland reaches under more arid climate (Fig. 6). Although this is a common natural pattern in arid zones (Jacobson et al., 2000), water impoundments of Mediterranean rivers exacerbate the situation, especially in the middle and lower reaches (Gasith \& Resh, 1999). A second environmental factor is the downstream increase in physical anthropogenic impacts on the channel, in parallel to the shorter hydroperiods and concomitant with a reduction in species richness and percentage stream cover by riparian vegetation, except by ruderal and nitrophilous species such as Artemisia barrelieri and the phreatophyte Tamarix canariensis (Fig. 6).

The trophic structure of the benthic community broadly matched the pattern of riparian vegetation variation (Fig. 6), in agreement with the "river continuum concept" (Vannote et al., 1980), at least in terms of resource-consumer relationships. However, mechanisms underlying the pattern in Mediterranean streams may differ substantially from those proposed by Vannote et al. (1980). Occurrence of macroinvertebrate shredders clearly correlated with high vegeta- 


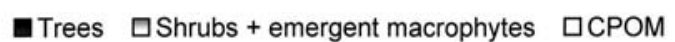

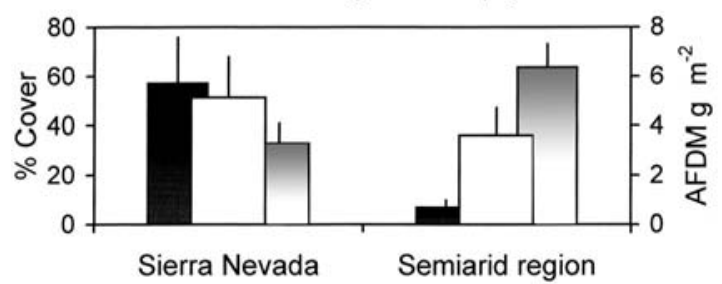

Figure 7. Percentage cover (mean $+1 \mathrm{SE}$ ) of two types of riparian vegetation at 3 Sierra Nevada sites and 4 semiarid sites of Almería. The second y-axis represents benthic coarse particulate organic matter (CPOM > $1 \mathrm{~mm}$ ) measured in December 1999 (unpublished data). AFDM = ash free dry mass. Porcentajes de cobertura (valores medios +1 error típico) de la vegetación riparia diferenciando estratos (árboles vs. arbustos y helófitos) para 3 localidades de Sierra Nevada y 4 de la región semiárida almeriense. El eje " $y$ " derecho representa la materia orgánica particulada gruesa (CPOM $>1 \mathrm{~mm})$ del bentos medida en diciembre de 1999 (datos no publicados). AFDM = Peso seco libre de cenizas.

tion cover by deciduous woody vegetation and/or emergent macrophytes at sites with permanent surface water flow. Similarly, the relative abundance of scrapers was associated with permanent headwater sites of the Río de Aguas, which has low discharge, abundant pool habitats, and intermediate cover by emergent macrophytes such that ample light reaches the stream bottom and allows algae and submerged macrophytes to develop abundantly. At the most impacted sites (mainly in the middle reaches of the Río Almanzora), with sparse riparian vegetation and short hydroperiods, the trophic structure was extremely simplified with an overwhelming abundance of invertebrate collectors (Fig. 6). These results suggest that trophic structure of the benthic macroinvertebrate community responds sensitively to changes in natural conditions and human disturbances in Mediterranean rivers. Trophic characterisation of macroinvertebrates may therefore be a useful approach to biomonitoring of these rivers, as in more humid temperate regions (e.g. Barbour et al., 1996).

According to Statzner \& Higler (1985) and several other studies (Davies et al., 1994; Schade \& Fisher, 1997), it is unusual to observe linkages between riparian vegetation structure, benthic resource availability and macroinvertebrate functional feeding groups in rivers under arid climates. This is thought to be due to the very irregular discharge regime (i.e. high spates and severe droughts), which makes resource availability highly unpredictable. The unusual link we observed in our two rivers might be attributable to the absence of spates during the two-year study. Additionally, or alternatively, it may be argued that the possible lack of coupling on the local scale may be masked by the strong environmental gradients at the regional scale.

Inputs of coarse particulate organic matter (CPOM) from riparian vegetation, mainly leaf litter, frequently constitute the main source of energy in forested headwaters. Fungi and macroinvertebrate shredders consume and transform these materials into fine particles, a resource more readily exploitable by bacteria and invertebrate collectors (Wallace \& Webster, 1996; Gessner et al., 1999). Several studies suggest that in rivers under arid climates riparian inputs are quantitatively and qualitatively less important for river food webs than in temperate forest streams (e.g. Schade \& Fisher, 1997). A comparative study between mountain headwaters from the Sierra Nevada and lowland headwaters in the semiarid region of Almería indicated, however, that despite large differences in riparian cover, the availability of CPOM for benthic macroinvertebrates may be relatively important even in semiarid permanent streams. The standing stock of benthic organic matter was not significantly different between regions (Fig. 7), probably due to the extensive cover of emergent macrophytes in the lowland streams, which make up for the virtual absence of a tree canopy. Furthermore, the retention of benthic organic matter in the semiarid region might be greater than in the Sierra Nevada as a consequence of less frequent discharge peaks.

Aquatic hyphomycete fungi appear to make a greater contribution to leaf litter decomposition in the Sierra Nevada streams, as deduced from the higher reproductive activity and biomass in streams of this region compared to streams in the semiarid lowland streams (Fig. 8). The diversity of aquatic hyphomycetes was also greater in the Sierra Nevada streams. Macroinvertebrates consuming leaf litter (in contrast) were similarly abundant and diverse in both regions (Fig. 9). Shredders belonging to the orders Plecoptera, 
Trichoptera and Diptera dominated in the Sierra Nevada streams, whereas scrapers, primarily the snail Melanopsis praemorsa, were most important and occasionally reached extremely high biomass in the semiarid lowland streams (Fig. 9). This snail is known to be an efficient consumer of leaf litter (Chergui \& Patte, 1991; Maamri et al., 1997; Heller \& Abotbol, 1997), feeding on leaf species of even very low food quality. As a result, the highest decomposition rate of leaf litter was recorded in our study at Molinos in the Río de Aguas, coinciding with a very rapid and extraordinarily high colonization of leaves by $M$. praemorsa (Fig. 9). Therefore, although autotrophic resources may be abundant because of the virtual absence of a tree canopy shading these semiarid headwaters, it is likely that CPOM inputs from riparian vegetation or emergent macrophytes are quickly consumed. This is facilitated by a high degree of trophic generalism of the macroinvertebrate consumers present in theses streams. Moreover, as such inputs of leaf litter are a donorcontrolled energy source, they may constitute a trophic alternative when autotrophic sources are limited as a result of intense grazing and/or the nutrient limitation of primary production.

\section{Leaf litter dynamics in travertine streams}

Calcium carbonate precipitation is a frequent, sometimes intense, event forming travertine or tuff in headwaters of the sierras in eastern Andalusia, where limestone-dolomite bedrock is abundant. Calcite precipitation may occur when groundwater rich in carbon dioxide and calcium is upwelling in the river channel and the outgassing $\mathrm{CO}_{2}$ shifts the $\mathrm{CO}_{2}$-carbonate equilibrium towards $\mathrm{CaCO}_{3}$, a process that can also be caused

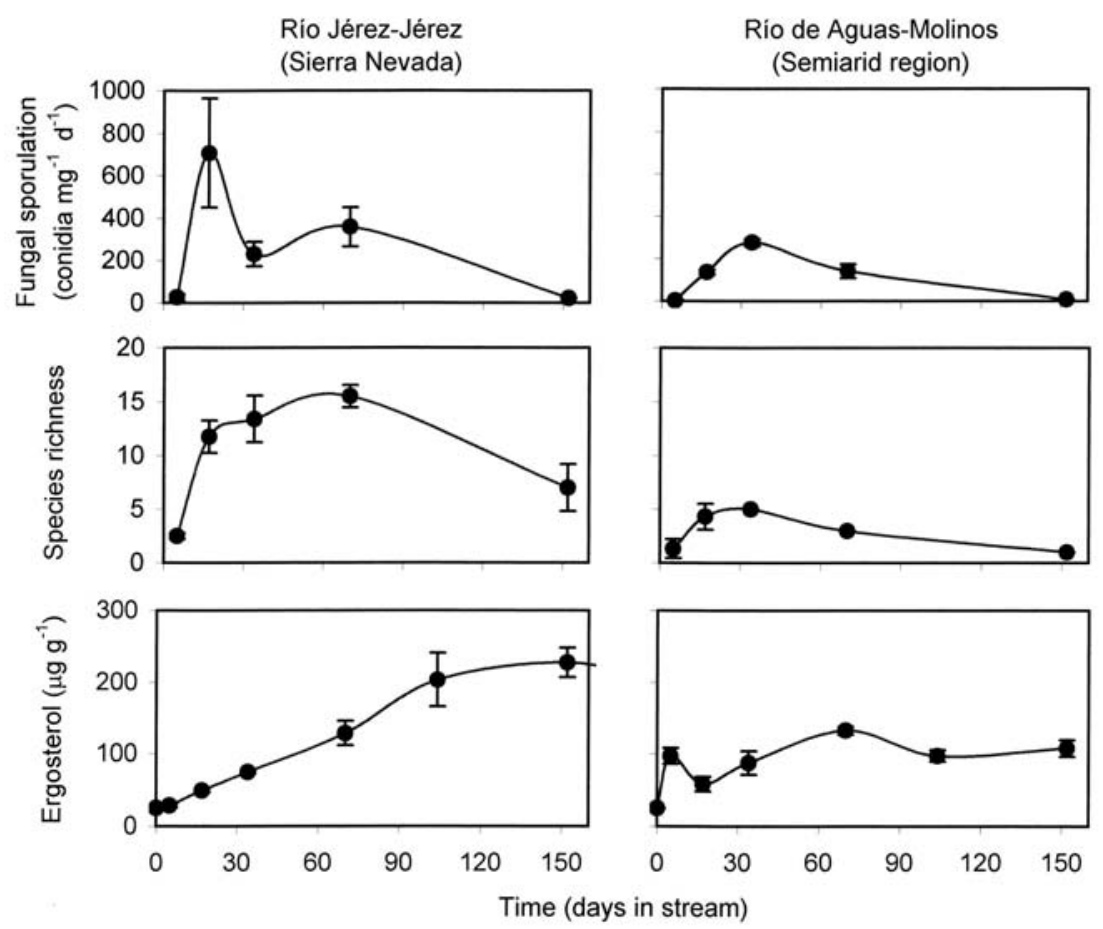

Figure 8. Fungal dynamics on decomposing alder leaves (Alnus glutinosa) in two contrasting streams (Sierra Nevada vs. semiarid region of Almería). Means $\pm 1 \mathrm{SE}(\mathrm{n}=4)$ are shown for each sampling date. Sporulation rates (conidia $\mathrm{mg}^{-1}$ leaf dry mass $\left.\mathrm{d}^{-1}\right) \mathrm{were}$ measured in vitro at stream temperature. Ergosterol is a fungal lipid frequently used as a proxy of fungal biomass (Gessner \& Newell, 2002). Dinámica de los hongos, aquaticos que intervienen en la descomposición de hojarasca de aliso (Alnus glutinosa) en dos ríos con gran contraste tipológico (Sierra Nevada vs. región semiárida almeriense). Se indican valores medios y error típico $(n=4)$ para cada fecha. Las tasas de esporulación (conidios $\mathrm{mg}^{-1}$ de peso seco de hojarasca $\mathrm{d}^{-1}$ ) se midieron mediante incubación in vitro a la temperatura del agua del rio. El ergosterol es un lipido específico de los hongos que se utiliza como indicador de la biomasa fúngica en la hojarasca (Gessner \& Newell, 2002). 

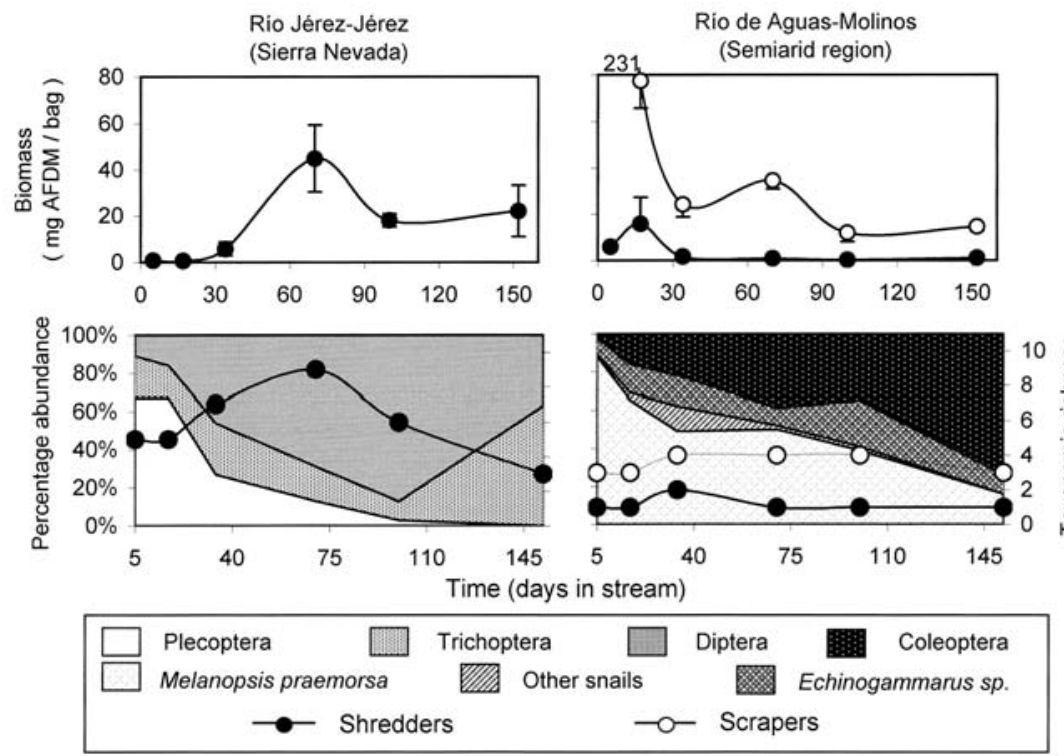

Figure 9. Dynamics of shredders and scrapers on decomposing alder leaf litter in two contrasting streams (Sierra Nevada vs. semiarid region of Almería). Symbols in the top panels show means \pm 1 SE of biomass $(n=4)$, symbols in the bottom panels show richness, and relative abundances for the main shredder and scrpaer taxa, as indicated by different shading. Note the extremely high value of scraper biomass (M. praemorsa) after only 5 days (231 mg per leaf bag). Dinámica de invertebrados (fragmentadores y raspadores) colonizadores de bolsas de hojarasca de aliso en dos ríos con gran contraste tipológico (Sierra Nevada vs. región semiárida almeriense). Los gráficos de biomasa ( $m g$ de peso seco libre de cenizas de invertebrados por bolsa) muestran valores medios y error típico ( $n=4$ ). Los datos de abundancia relativa y riqueza corresponden a los principales taxones de fragmentadores y raspadores representados por diferentes tramas. Nótese que en el gráfico de biomasa para la localidad semiárida el valor de raspadores a los 5 días es $231 \mathrm{mg}$ por bolsa.

by $\mathrm{CO}_{2}$ removal through photosynthesis. Studies in a travertine stream in the Sierra de Almijara (Casas et al., 1994; Casas \& Descals, 1997; Casas \& Gessner, 1999; Vivas \& Casas, 2002) have highlighted the key role of this process often exerts in ecosystem energy flow, mainly by interfering negatively with the action of microbial decomposers and detritivores. Two sites were studied in this stream, one devoid of riparian vegetation and experiencing intense travertine precipitation, the other covered by a canopy of riparian woody vegetation and reduced travertine precipitation. Large differences in standing stocks of benthic CPOM between both sites reflected the differences in riparian vegetation. Benthic CPOM stocks were remarkably high at the vegetated site compared to other studies, probably due to the extraordinary retention capacity of this type of travertine streams because riparian inputs typically become encrusted with calcite and firmly cemented to the stream bottom. Additionally, benthic CPOM stocks may be partly due to low decomposition rates. In fact, the leaf species examined exhibited decay rates among the lowest recorded in the literature, and rates were significantly lower at the open site with massive high travertine precipitation (Casas \& Gessner, 1999). The calcite crust, which forms on CPOM rather quickly, probably acts as an effective barrier preventing physical abrasion and also hindering decomposition by both microbes and detritivores. Accordingly, the species richness and reproductive activity of aquatic hyphomycete fungi associated with leaves were lower at the open site with higher travertine precipitation (Casas \& Descals, 1997), as was the biomass of detritivores (Vivas \& Casas, 2002).

These data indicate that in Mediterranean streams that are prone to travertine precipitation, basal resources such as leaf litter but also algal or bacterial biofilms on rocks are difficult to exploit for primary consumers. However, a well-developed woody riparian vegetation may significantly enhance energy flow in these streams not just by providing organic matter inputs but also by reducing tuff formation on the stream bed. 


\section{Conclusions and perspectives}

The results presented above illustrate the diversity of fluvial ecosystems in eastern Andalusia. The pronounced altitudinal, climatic and geological gradients in the area provide a wide range of natural conditions, superimposed by human impact. This sitting makes the area are well suited to carry out theoretical and applied studies on river ecology, particularly comparative investigations. The studies carried out to date have been mostly descriptive. The hypotheses they have generated now require experimental testing. Long-term observations are also needed to provide information on fluvial ecosystem dynamics at large time-scales, especially in view of the important interannual variability typical of the Mediterranean climate. In addition, our results highlight the conspicuous effects of human impacts on rivers in eastern Andalusia. This is another piece of evidence documenting the vast human pressures on aquatic ecosystems, which are likely to have particularly severe consequences in the Mediterranean where scarce and irregular rainfall is combined with everincreasing water demands and diverse sorts of surface water contamination. Headwater reaches may partly escape from this pressure, since they are often located in sierras that benefit from some sort of environmental protection status. However, even these streams are subject to human activities in their basins. A variety of farming, forestry and tourist activities are allowed in natural parks, and together with the overexploitation of groundwater, they may impair the ecological integrity of these rivers if preventive measures are not taken. The ambitious environmental objectives of the European Water Framework Directive to secure ecological sustainability of rivers are a step in the right direction, from which the rives in Andalusia may benefit.

\section{ACKNOWLEDGEMENTS}

Professor Ramón Margalef was a friend and outstanding scientist whose ideas were a guiding force for us and surely will continue inspi- ring new generations of limnologists. His death is an irreparable loss to many of us. We are grateful to Joan Armengol for having invited us to joint in this tribute. A substantial part of the results discussed in the present contribution has been funded by the Spanish "Ministerio de Educación y Ciencia" as part of the following projects: GUADALMED-1 (HID98-0323-C0504), GUADALMED-2 (REN2001-3438-C0705), and CGL2004-02496.

\section{REFERENCES}

ALLAN, J. D. 1995. Stream Ecology. Structure and Function of Running Waters. Chapman \& Hall, London. 388 pp.

BARBOUR, M. T., J. GERRITSEN, G. E. GRIFFITH, R. FRYDENBORG, R. MCCARRON, J. S. WHITE \& M. L. BASTIAN. 1996. A framework for biological criteria for Florida streams using benthic macroinvertebrates. J. N. Am. Benthol. Soc., 15: $185-211$.

BLONDEL, J. \& J. ARONSON. 1999. Biology and Wildlife of the Mediterranean Region. Oxford University Press, Oxford. 328 pp.

BOULTON, A. J., C. G. PETERSON, N. B. GRIMM \& S. G. FISHER. 1992. Stability of an aquatic macroinvertebrate community in a multi-year hydrologic disturbance regime. Ecology, 73: 2192-2207.

BOULTON, A. J. 2003. Parallels and contrasts in the effects of drought on stream macroinvertebrate assemblages. Freshwat. Biol., 48: 1173-1185

CALLE, D., A. VÍLCHEZ-QUERO, J. J. CASAS \& M. C. LUQUE-CASTILLO. 1990. Estudio de la calidad de las aguas del río Guadalquivir y algunos afluentes de la cuenca alta: factores físicoquímicos. Naturalia Baetica, 3: 1-146.

CALLE, D. \& J. J. CASAS. 2006. Chironomid species, stream classification and water-quality assessment: The case of two Iberian Mediterranean mountain regions. J. N. Am. Benthol. Soc., 25: 465-476.

CAPEL-MOLINA, J. 2000. El clima de la península Ibérica. Ariel Geografía, Barcelona. 282 pp.

CASAS, J. J. 1990. Estudio faunístico, sistemático y ecológico de los quironómidos (Diptera: Chironomidae) de los ríos de Sierra Nevada: Composición y estructura de sus comunidades. Tesis Doctoral, Universidad de Granada. 415 pp.

CASAS, J. J. 1996. Dinámica espacio-temporal de las características físico-químicas de un río de 
montaña no regulado sometido a vertidos de aguas residuales: una aproximación multivariante. Actas del IV Simposio sobre el Agua en Andalucía II, Almería, España: 249-255.

CASAS, J. J. \& E. DESCALS. 1997. Aquatic hyphomycetes from Mediterranean streams contrasting in chemistry and riparian canopy. Limnetica, 13: 45-55.

CASAS, J. J. \& M. O. GESSNER. 1999. Leaf litter breakdown in a Mediterranean stream characterised by travertine precipitation. Freshwat. Biol., 41: 781-793.

CASAS, J. J., J. PICAZO \& M. L. CARCELEN. 1994. Leaf packs breakdown in a Mediterranean karstic stream. Verh. Internat. Verein. Limnol., 25: 1739-1744.

CASTILLO-REQUENA, J. M. 1981. Precipitaciones y tipos de tiempos en las Béticas-Alto Guadalquivir (Andalucía Oriental). Memoria de Licenciatura. Universidad de Granada. Instituto Nacional de Meteorología, Madrid. 295 pp.

CHERGUI, H. \& E. PATTEE. 1991. An experimental study of the breakdown of submerged leaves by hyphomycetes and invertebrates in Marocco. Freshwat. Biol., 26: 97-110.

DAVIES, B. R., M. C. THOMS, K. F. WALKER, P. O'KEEFFE \& J. A. GORE. 1994. Dryland rivers: Their ecology, conservation and management. In: The River Handbook, vol. 1. P. Calow \& G. E. Petts (eds.).: 484-511. Blackwell Science, Oxford.

DURÁN, J. J. \& J. LÓPEZ (eds.). 1999. Karst en Andalucía. Instituto Tecnológico Geominero de España, Madrid. 178 pp.

GASITH, A. \& V. H. RESH. 1999. Streams in Mediterranean climate regions: Abiotic influences and biotic responses to predictable seasonal events. Ann. Rev. Ecol. Syst., 30: 51-81.

GESSNER, M. O., E. CHAUVET \& M. DOBSON. 1999. A perspective on leaf litter breakdown in streams. Oikos, 85: 377-384.

GESSNER, M. O. \& S. Y. NEWELL. 2002. Biomass, growth rate, and production of filamentous fungi in plant litter. In: Manual of Environmental Microbiology, 2nd ed. C. J. Hurst, R. L. Crawford, G. R. Knudsen, M. J. McInerney \& L. D. Stetzenbach (eds.): 390-408. ASM Press, Washington, DC.

GILLER, P. \& B. MALMQVIST. 1998. The Biology of Streams and Rivers. Oxford University Press, Oxford.

GREGORY, S. V., F. J. SWANSON, W. A. McKEE \& K. W. CUMMINS. 1991. An ecosystem perspective of riparian zones. BioScience, 41: 540-550.
GROVE, A. T. \& O. RACKHAM. 2001. The Nature of Mediterranean Europe. An Ecological History. Yale University Press. New Haven and London. 384 pp.

HAWKINS, C. P., R. H. NORRIS, J. GERRITSEN, R. M. HUGHES, S. K. JACKSON, R. K. JOHNSON, R. \& J. STEVENSON. 2000. Evaluation of the use of landscape classifications for the prediction of freshwater biota: synthesis and recommendations. J. N. Am. Benthol. Soc., 19: 541-556.

HELLER, J. \& A. ABOTBOL. 1997. Litter shredding in a desert oasis by the snail Melanopsis praemorsa. Hydrobiologia, 344: 65-73.

HYNES, H. B. N. 1970. The Ecology of Running Waters. Liverpool University Press, Liverpool. $555 \mathrm{pp}$.

JACOBSEN, D. 2004. Contrasting patterns in local and zonal family richness of stream invertebrates along an Andean altitudinal gradient. Freshwat. Biol., 49: 1293-1305.

JACOBSEN, D., R. SCHULTZ \& A. ENCALADA. 1997. Structure and diversity of stream macroinvertebrate assemblages: the effect of temperature with altitude and latitude. Freshwat. Biol., 38: 247-261.

JACOBSON, P. J., K. M. JACOBSON, P. L. ANGERMIER \& D. S. CHERRY. 2000. Hydrologic influences on soil properties along ephemeral rivers in the Namib Desert. J. Arid Environ., 45: 21-34.

LAKE, P. S. 2003. Ecological effects of perturbation by drought in flowing waters. Freshwat. Biol., 48: 1161-1172

LANGTON, P. H. \& J. J. CASAS. 1999. Changes in chironomid assemblage composition in two Mediterranean streams over a period of extreme hydrological conditions. Hydrobiologia, 390: 37-49.

MAAMRI, A., H. CHERGUI \& E. PATTEE. 1994. Allochthonous inputs of coarse particulate organic matter to a Moroccan mountain stream. Acta. Oecol., 15: 495-508.

MALANSON, G. P. 1993. Riparian Landscapes. Cambridge University Press, Cambridge. 296 pp.

MARGALEF, R. 1960. Ideas for a synthetic approach to the ecology of running waters. Int. Revue ges. Hydrobiol., 45:133-153.

MARGALEF, R. 1974. Ecología. Omega, Barcelona. $951 \mathrm{pp}$.

MARGALEF, R. 1983. Limnología. Omega, Barcelona. 1010 pp.

MÉDAIL, F. \& P. QUÉZEL. 1999. Biodiversity hotspots in the Mediterranean Basin: Setting global conservation priorities. Conserv. Biol., 13: 15101513. 
MILNER, A. M., J. E. BRITTAIN, E. CASTELLA \& G. E. PETTS. 2001. Trends of macroinvertebrate community structure in glacier-fed rivers in relation to environmental conditions: a synthesis. Freshwat. Biol., 46: 1833-1847.

MONSERRAT, P. 1998. Dinamismo ecológico-cultural en el paisaje mediterráneo. In: El paisaje mediterráneo. J. Arias \& F. Fourneau (eds.): pp. 107116. Colección Monográfica Tierras del Sur, Universidad de Granada \& Junta de Andalucía, Granada.

MYERS N., R. A. MITTERMEIER, C. G. MITTERMEIER, G. A. B. DA FONSECA \& J. KENT. 2000. Biodiversity hotspots for conservation priorities. Nature. 403: 853-858.

NAIMAN, R. J., H. DECAMPS \& M. McCLAIN. 2005. Riparia - Ecology, Conservation, and Management of Streamside Communities. Academic Press. San Diego. 448 pp.

RÜEGG, J. \& C. T. ROBINSON. 2004. Comparison of macroinvertebrate assemblages of permanent and temporary streams in an Alpine flood plain, Switzerland. Arch. Hydrobiol., 161: 489-510.

SABATER, S., H. GUASCH, E. MARTÍ, J. ARMENGOL, M. VILA \& F. SABATER. 1992. The Ter, a Mediterranean river system in Spain. Limnetica, 8: 141-149.

SCHADE, J. D. \& S. G. FISHER. 1997. Leaf litter in a Sonoran Desert stream ecosystem. J. N. Am. Benthol. Soc., 16: 612-626.

STATZNER, B. \& B. HIGLER. 1985. Questions and comments on the river continuum concept. Can. J. Fish. Aquat. Sci., 42: 1038-1044.

TOWNSEND, C. R. 1989. The patch dynamics concept of stream community ecology. J. N. Am. Benthol. Soc., 8: 36-50.
VANNOTE, R. L., G. W. MINSHALL, K. W. CUMMINS, J. R. SEDELL \& C. E. CUSHING. 1980. The river continuum concept. Can. J. Fish. Aquat. Sci., 37: 130-137.

VIVAS, S. 2003. Comunidades de macroinvertebrados de los ríos Aguas y Almanzora: Relaciones con la evaluación del estado ecológico. Tesis Doctoral, Universidad de Almería. 222 pp.

VIVAS, S. M. BAYO, D. LÓPEZ \& J. J. CASAS. 2001. Variabilidad espacio-temporal de la físico-química en dos ríos bajo clima semiárido: Río Almanzora y Río Aguas (Almería). Actas del V Simposio sobre el Agua en Andalucía II, Almería, España: 313-321.

VIVAS, S., J. J. CASAS, I. PARDO, S. ROBLES, N. BONADA, A. MELLADO, N. PRAT, J. ALBATERCEDOR, M. ÁLVAREZ, M. M. BAYO, P. JÁIMEZ-CUELLAR, M. L. SUÁREZ, M. TORO, M. R. VIDAL-ABARCA, C. ZAMORA-MUÑOZ, G. MOYÁ. 2002. Aproximación multivariante en la exploración de la tolerancia ambiental de las familias de macroinvertebrados de los ríos mediterráneos del proyecto GUADALMED. Limnetica, 21: 149-173.

VIVAS, S. \& J. J. CASAS. 2002. Macroinvertebrates colonising leaf litter of contrasting quality in a travertine Mediterranean stream. Arch. Hydrobiol., 154: 225-238.

WALLACE J. B \& J. R. WEBSTER. 1996. The role of macroinvertebrates in stream ecosystem function. Ann. Rev. Entomol. 41: 115-139.

WARD, J. V. \& J. A. STANFORD. 1982. Thermal responses in the evolutionary ecology of aquatic insects. Ann. Rev. Entomol., 27: 97-117.

WILLIAMS, D. D. 1996. Environmental constraints in temporary fresh waters and their consequences for the insect fauna. J. N. Am. Benthol. Soc., 15: 634-650. 